\title{
Effects of News Talk Shows in Voting Behavior
}

\section{Gautam RK*}

Kasturbagram Rural Institute, Kasturbagram, Near- Tejaji Nagar, Khandwa Road, Indore, Madhya Pradesh

\begin{abstract}
The main purpose of this paper is to find out the influence of News Talk Shows in creating political efficacy among educated youth. The researcher wants to measure the level of political efficacy, that is, level of awareness and level of political participation based on the fact that how much educated youth are influenced by News Talk Shows regarding politics. News Talk Shows are helpful in changing the political structure, political system and political development. Media is a lifeline of socialization. This Paper also develops a framework of political socialization in India. Public opinion is made in democracy by voting and responding to polls besides participating in elections. Special emphasis has been put on electioneering campaigns, voting behaviors and role of media in creating political awareness. Universe for the present study consists of Devi Ahilya University Students, Indore. The researcher has selected 100 samples in nineteen departments of this university.
\end{abstract}

Keywords: News talk shows; Political efficacy; Voting behavior

\section{Introduction}

Media plays an important role in creating political awareness among the people and ensures their participation in the democratic process. It also plays a significant role in bringing changes in the society. Today, every one of us is spending more of our leisure time watching TV, listening to the radio or reading newspapers and magazines. The shows on the TV and the articles in the newspapers influence our decision process, shaping our perceptions for the world. Besides the positive fact that we are better informed and in touch with the latest news, we should be aware that accepting this enormous flow of information and allowing it to make our mind can be dangerous. The TVs infiltrate our lives, guiding us what are we supposed to wear, how we are supposed to look and act.

Mass media always had been an important means of communication. Over a period of time it has passed through various changes and has gradually acquired a new significance and importance in the present times. Earlier it used to be small in size and in the strict control of the authoritarian governments to "Control Public Mind". India too has its share, along with the government channels; there are several private channels available on cable TV network. Channel are busy round the clock on regional and national level showing great variety of programs of Entertainment, Information, Religious, Discussions and Talk Shows, etc. The role of media is gaining importance every day. It is fast transforming itself and in turn becoming an agent of transforming the world. Now Media is helping democracies and promoting globalization. "By adopting a global outlook, we become more aware of our connections to people in other societies. The global perceptive opens our eyes to the fact that our increasing ties with the rest of the world means that our actions have consequences for other and the world's problems have consequences force us [1]. The institution of politics is one of the institutions which work for the welfare of people and concerned with government and other related issues of government, elections, vote, etc. In most of the world's countries, national power of politics and authority are allocated to various individuals and groups through politics, usually by means of compromises between conflicting interests. Through politics, governments are elected or appointed, or in some cases, created by armed forces. Governments have the power to make, interpret and enforce the rules and decisions that determine how to run the countries. In the present era, it has been seen that Mass Media has put spirit and encouraged people in electing government according to their own choice. In this way, people can change the wrongful decision of government officials. So Mass Media is the source of influencing people to participate in politics and this is the only source of creating awareness in citizens that how to improve and run our political system. People are mainly affected by the news and news talk shows that are on air on different news channel of India around the clock. Every news talk show, may it be Capital talk or live with Talat or any other, it starts with a topic and ends with a conclusion which is normally drawn by the anchor himself. People may or may not agree with the conclusion drawn by the anchor. Opinionated news has always been a hard pill to swallow in any society. People who do not agree with the opinion will call that anchor to be biased. Then comes the policy of channels, which is originally never exposed, on the face of it every channel claims to have the policy of nondiscriminatory, unbiased anti racialism and non-prejudice but widely held believe remains that different channel support different political parties and social groups.

\section{Profile of Indian Youth}

Here, firstly we discuss the role of Indian youth in the electoral process. Prior to this discussion, let us first examine the characteristics of Indian youth today. Youth may be defined as people aged between 15-24 years. India is a young nation. Median age of Indians is 24 years. The following are the major characteristics of Indian youths. According to 2001 Census, out of 1029 million people, 195 million (18.95\%) are youths. High illiteracy: $31 \%$ of young women and $14 \%$ of young men are illiterate. $41 \%$ of adolescents aged $15-17$ years attended school in the school year 2005-06. Media exposure: Most youths are exposed to media like television, radio, etc. Gender roles: Youth attitudes to gender roles are no more egalitarian than that of age group 25-49. "Thus the preparation of youth for the challenges of nation building is very limited", observe Sulabh Parasuraman, Sunita Kishore, Shri Kant

*Corresponding author: Gautam RK, Lecturer, Kasturbagram Rural Institute, Kasturbagram, Near-Tejaji Nagar, Khandwa Road, Indore, Madhya Pradesh, Tel: 08602550091; E-mail: rishi.news24@gmail.com

Received September 17, 2014; Accepted June 26, 2015; Published June 30, 2015

Citation: Gautam RK (2015) Effects of News Talk Shows in Voting Behavior. J Mass Communicat Journalism 5: 262. doi:10.4172/2165-7912.1000262

Copyright: (c) 2015 Gautam RK. This is an open-access article distributed under the terms of the Creative Commons Attribution License, which permits unrestricted use, distribution, and reproduction in any medium, provided the original author and source are credited. 
Singh, Y Vaidehi, in their study prepared for the Ministry of Health and Family Welfare, Government of India [2].

\section{Views on youth participation in politics}

Some political observers are of the view that youths are not participating in politics to the desired extent. Noted sociologist, Y B Damle, distinguished between 'student youth' and nonstudent youth. He noted that for the student youth, the pressure of career and the desire for prestigious jobs make them impervious to an ideology which requires understanding and action. The non-student youth are so much preoccupied with making a living that for them also ideology based political action is not possible [3]. Many political observers in the 21st century would agree with Damle's assessment. Thus, Latha Narayan, an academician, holds that "The youth have opted to compromise rather than fight injustice. Their energies are mainly spent in the 'self-survival' process rather than in building the nation.' She further observes that politics is equated with unfair power games, and hence, a significant number of the youth shun it. In the broadest sense of the term, political action is the process of change being guided by a political understanding of social realities. Imran Khan, a popular actor in Bollywood, virtually echoes her. "Young people want to bring in change but they feel their voices are bound to get lost in the political rhetoric. They prefer to opt out rather than be a part of the same structure." All observers however do not agree with the view that youth are politically apathetic. Thus, Manisha Natarajan claims that in the 5.5 lakh panchayats in rural areas, several lakh young men and women are serving as office bearers in various capacities like panch, sarpanch, etc. Seventy percent of them are below the age of 35 . So, there is no substance in the allegation that youth are apathetic to politics. She further observes: "Surely that is evidence enough to show that the young are interested in entering the system to change their village communities? If the urban young are apathetic about politics it is largely because of the system's penchant for political institutions, the closed door functioning of political outfits and the special status given to politicians. These are all negative factors and breed revulsion among ordinary people."

\section{Efficacy}

Efficacy is the capacity to produce a desired size of an effect under ideal or optimal conditions. It is these conditions that distinguish efficacy from the related concept of effectiveness, which relates to change under real life conditions.

\section{Political efficacy}

Political efficacy is an attitude and a phenomenon of socio-political context. It is the term that describes people's feelings of government, it examines whether or not people feel they are being taken seriously or not. But some people have strong sense of political efficacy while others do not. This is mostly derivative of people's experiences. "Political efficacy is the extent to which an individual feels that his or her participation in politics will be effected" [4]. According to the research by Axford and Browning, it is commonly measured and used an as indicator for the boarder health of civil society. Feelings of efficacy are highly correlated with participation in social and political life. Public opinion studies have conventionally treated political efficacy as two dimensional concepts involving internal and external efficacy or in other words political efficacy has two types:

Internal efficacy: Internal efficacy is the perception that one has the requisite skills and resources to influence the Political system.

External efficacy: External efficacy is the perception that government institutions and elites are responsive to one's attempt to exert political influence. Internal efficacy has only a limited relationship with the depended variables, though high levels of internal efficacy are found to be a condition for collective and external efficacy to exert stronger impact on political attitude and behavior. According to a research "Engaging the Electorate (Initiatives to promote voter turnout from around the world)" by Andrew Eills, an important indicator of political efficacy is voter participation. "A sense of efficacy is developed when an individual feels well-informed enough about politics to believe that they can influence the makeup or activities decision making bodies, if an election appears to be meaningless or irrelevant, or an individual feels powerless or ineffectual in his or her interactions with the political system, the sense of political efficacy declines and abstention from this can lead to political apathy and alienation [5]. When we talk about political institution, political efficacy is an important aspect. Political efficacy refers generally to citizens' beliefs in their ability to influence the political system. An individual's sense of political efficacy is important because it is associated with political participation, the acquisition of political information and discussion of the political issues. The present study is focused to measure the level of political efficacy among educated youth.

\section{Research Design}

The main purpose of this research is to find out relationship between role of News Talk Shows and political efficacy. Following are the objectives of the research:

- To find out the influence of news talk shows in creating political efficacy among Devi Ahilya University.

- To measure the level of political efficacy based on political information, political awareness and political participation among educated youth.

The research methods in the present study are qualitative. The universe of the present research is Devi Ahilya University. The researcher selected the 100 respondents from this university aged between $18-25$ years.

\section{Finding of the Study}

The researcher has given a comprehensive overview of the sample characteristics and interpretation of them, the distribution of the responses of the educated youth about news talk shows and political efficacy. Question is that how many respondents believe news talk shows as source of awareness about political affairs. 58 percent, majority of the respondents believe that they get awareness about political affairs through news talk shows, 19 percent of the respondents reported their agreement to the fact that news talk shows are improving political awareness. 10 percent remained neutral and only 8 percent of the respondents strongly disagreed with the notion that talk shows are improving political awareness. This analysis indicates that majority of the respondents consider that news talk shows are improving knowledge and awareness about political affairs.

About the importance of News Talk Shows and whether these can be helpful in changing the political structure. Majority of the respondents, 41 percent of the respondents agree that news talk shows are playing the role in changing Political Structure (Political structure consists of Election Procedures, Rules and Regulations related to politics and institutions like National and Provincial Assemblies and Senate). Other 24 percent of the respondents disagreed that news talk shows are playing role in Political Structure because they believe that there 
is no role of news talk shows with respect of changing the political structure. Represents the information about those who believe that they have ability to select government of their own choice. Majority, 41 percent of the respondents reported that their view is neutral where as 28 percent of the respondents disagreed about ability to select government of one's own choice and only 16 percent agreed with the fact that they have the ability to select government of their own choice. This indicates that majority of the respondents do not believe that they can select a government of their choice. Indicates the information about the respondent's awareness about their political rights that how many of them have awareness for their political rights. It indicates that only 15 percent of respondents are those who have awareness about their political rights and majority 64 percent of is not aware about their political rights. This analysis shows that majority of has no awareness about political rights and they do not know that "Right to Vote" is a political rights. About the views of the respondents about the present situation of the country that how they feel for this situation of the country. 49 percent of the respondents feel sad about present situation of the country, 40 percent not feel satisfied, 8 percent of the respondents feel satisfactory and 2 percent feel good and one respondent out of 120 had no answer about present situation of the country. This analysis indicates that majority of the respondents are disappointed with the present situation of the government. Highlights opinion of respondents that how they perceive whether the government is playing its role effectively or not. There is only 2 percent of the respondents reported that government is playing effective role, 2 percent strongly agreed, 53 percent strongly disagreed, 10 percent of the respondents remained neutral and one of the respondents did not answer [6].

\section{Conclusion}

The present study was exploratory study in which main objectives were to access whether news talk shows are enhancing the level of political efficacy among educated youth, political participation, awareness level of youth for politics and their views and opinions about politics and other political bodies. Concluded points of the present study are as follow: Respondents who watch news talk shows have great level of political knowledge, knowledge about different organs of government and structure of India's political system than those respondents who do not watch. Analysis showed that news talk shows are increasing the political awareness and political socialization of the viewers. Most of the respondents have political awareness about news talk shows but yet they do not participate in politics except few of them. Some respondents have no awareness about their political rights; they do not know their rights and how they can use them. There is a very low percentage of youth who have awareness about their political rights. Gender difference is very important because female participation is very low in voting, election campaign and student politics than the participation of males and those individuals who are involved in political activities are males. Female students are less interested in politics as compared to male students. There is very low participation of youth in political activities, because most of the youth is not interest in politics and have low political efficacy, the reason for this is that educated youth have no trust and faith in political bodies and they do not trust the political system as well. There is a very low voter turnout by youth because majority of the youth have no trust in voting process and politicians and that is why most of the youth do not like to cast a vote, they consider it as a useless activity because in their opinion voting process and elections are not transparent. Most of the respondents have apathetic behavior towards politics and political system of India; there are many reasons for this behavior, such as, illegitimate use of authority, corruption, by politicians. Majority of the respondents consider that the present government is not playing its role effectively. Educated youth can bring the rapid change in the political culture and system of India they have more knowledge, ideas and better suggestions to control the present political situation. Respondents reported that news talk shows are a source of spreading the confusion and frustration among people because due to news talk shows viewers are losing their ability to think and analyze the things, they are getting influenced and believing whatever news talk shows are representing.

\section{References}

1. Mark R (1978) Understanding of effects of TV on human behavior is one of the most difficult but also one of the most important problems facing the social science community today. American Journal of Sociology.

2. Yorke I (2006) Television News: who does what in television news? (4th Ed) Focal Press Boston.

3. Bansal SK (2007) Journalism and Electronic Media: Electronic media in women development. A.P.H. Publishing Corporation, New Delhi.

4. Babbie E (1994) Critique of Rappeport's litigation Surveys-Social "Science" as Evidence. Official Journal of the International Trademark Association 92: 14801501.

5. Koplatadze B (2004) Media Coverage of the 2003 Parliamentary Election in the Republic of Georgia. Routledge Publishers, British.

6. Jordan DL (2008) Using Media Consumption to Explain Political Identification and behavior and Perceptions of the News Media. University of Waterloo, Ontario, Canada. 